\title{
INSULIN-LIKE GROWTH FACTOR BINDING PROTEINS AND MITOGENIC ACTIVITY OF PARTIALLY FRACTIONATED SHEEP AMNIOTIC FLUID
}

\author{
J. Blahovec ${ }^{1 *}$, Zuzana KosteckÁ ${ }^{1}$, Françoise CAVAille ${ }^{2}$, M. G. LacroiX ${ }^{3}$ \\ and J. MESTER ${ }^{4}$ \\ ${ }^{1}$ Department of Chemistry, Biochemistry and Biophysics, University of Veterinary \\ Medicine, 04181 Košice, Komenského 73, Slovakia; ${ }^{2}$ INSERM U 142, Hôpital \\ St.-Antoine, Paris, France; ${ }^{3}$ Unité de Recherche sur l'Endocrinologie du Placenta et de la \\ Périnatalité, INRA, Jouy-en Josas Cedex, France; ${ }^{4}$ INSERM U 55, Hôpital St.-Antoine, \\ Paris, France
}

(Received March 22, 2000; accepted May 3, 2000)

\begin{abstract}
Amniotic fluid collected from ewes on various days of gestation was examined for the presence of insulin-like growth factor (IGF) binding proteins. IGFbinding proteins with a molecular mass of $40-45 \mathrm{kDa}$ appeared at day 41 of gestation. The level of these major IGF-binding proteins increased during pregnancy and reached a maximum at day 106. Smaller IGF-binding molecules with an approximate molecular mass of $35 \mathrm{kDa}$ and $25 \mathrm{kDa}$ appeared at day 90 , also reaching a concentration peak at day 106. The mitogenic activity of sheep amniotic fluid after chromatography on Sephadex G-50 was separated into two peaks. The peak having lower molecular mass corresponded to an elution profile of ${ }^{125} \mathrm{I}-\mathrm{IGF}$ I. The first peak, having higher molecular mass, was eluted immediately after the void volume of column. Electrophoresis and ligand blotting showed that proteins in the first peak had similar properties as IGF-binding proteins.
\end{abstract}

Key words: Amniotic fluid, sheep, growth factors, binding proteins

Binding proteins of peptidic growth factors are now considered to be one of the direct variables that, together with growth factors and their cell receptors, play a key role in the regulation of prenatal growth and development. Recently it has been shown that growth factors and their binding proteins may act on the $\mathrm{d}$ evelopment of the gastrointestinal and pulmonary tracts after resorption or inhal ation of amniotic fluid by the fetus (Itakura et al., 1997; Kelly et al., 1997). In human and animal amniotic fluid, besides insulin-like growth factors (IGFs, fo rmerly also called somatomedins), several specific IGF-binding proteins (IGFBPs) have also been found which form firm complexes with IGFs. As these complexes have very low $\mathrm{K}_{\mathrm{d}}\left(\sim 10^{-9} \mathrm{~mol} / \mathrm{l}\right)$, it is acceptable that IGFBPs act ge $\mathrm{n}$ erally as inhibitors of the mitogenic activity of somatomedins. However, contr o-

*E-mail: kostecka@uvm.sk 
versial findings have also been reported in the literature for complexes of som atomedins with their binding proteins which in some cases can augment the ability of IGFs to increase DNA synthesis (Elgin et al., 1987; Koistinen et al., 1990).

The aim of this work was to investigate the presence of IGFBPs in sheep amniotic fluid in relation to days of gestation. We also demonstrate the ability of partially purified fractions of sheep amniotic fluid to increase the proliferation of mouse fibroblast cell culture (BP-A31 cells).

\section{Materials and methods}

\section{Chemicals}

The gels and buffers for polyacrylamide gel electrophoresis were purchased from Pharmacia (Uppsala, Sweden). IGF-I and IGF-II were from Novo (Copenhagen, Denmark). All other reagents were from regular commercial sources.

\section{Amniotic fluid}

The amniotic fluid was collected at various times of pregnancy by pun cture of the amniotic sac. All samples were delipidated with chloroform and stored in lyophilized form. Three animals were used throughout the work without notable differences in the results obtained.

\section{Fractionation}

Amniotic fluid was subjected to chromatographic separation on Sephadex G-50 column $(3 \times 90 \mathrm{~cm})$ under acidic conditions $(10 \%$ acetic acid $)$. Elution was performed using a $10 \%$ acetic acid at a flow rate $9.5 \mathrm{ml} / \mathrm{h}$. Fraction volume was $9.5 \mathrm{ml} / \mathrm{h}$. After measurement of absorbance at $280 \mathrm{~nm}$ all fractions were lyophilized and tested for mitogenic activity. The position of elution of ${ }^{125}$ I-IGF-I as well as the void volume (elution of Blue Dextran) and the total volume (elution of p otassium chromate) were subsequently established under the same cond itions.

\section{Cell culture}

Benzo-a-pyrene-transformed BALB/c 3T3 mouse fibroblasts (BP-A31 cells) were cultured in a-Minimum Essential Medium supplemented with $6 \% \mathrm{f} \mathrm{e}$ tal calf serum in a humidified atmosphere containing $5 \% \mathrm{CO}_{2}$. For the study of mitogenic effects, the cells were seeded in 24 -well boxes (40,000 cells per well). After $24 \mathrm{~h}$, the medium was replaced with $1 \mathrm{ml}$ serum-free a- MEM plus $2.5 \mu \mathrm{M}$ $\mathrm{FeSO}_{4}$ and the cells were allowed to enter quiescence during the next $48 \mathrm{~h}$. 


\section{Incorporation of ${ }^{3} H$-thymidine}

The cells were incubated with $2 \mu \mathrm{Ci}{ }^{3} \mathrm{H}$-thymidine and fractions of amn iotic fluid for $24 \mathrm{~h}$. The incorporation of ${ }^{3} \mathrm{H}$-thymidine was terminated by acidif $\mathrm{i}$ cation with $1 \mathrm{~mol} / 1$ ascorbic acid (three drops per $\mathrm{ml}$ ). The cells were fixed with $5 \%$ trichloroacetic acid, solubilised in $0.1 \mathrm{~mol} / 1 \mathrm{NaOH}$ and the incorporated $\mathrm{r}$ adioactivity was determined by liquid scintillation counting.

\section{Polyacrylamide gel electrophoresis (PAGE) and ligand blotting}

The procedure was identical to that described by Hossenloop et al. (1986). Portions of total amniotic fluid or of fractions to be analyzed were adjusted to $1 \%$ sodium dodecyl sulphate (SDS) in non-reducing Laemmli sample buffer and boiled for $5 \mathrm{~min}$. The samples were then fractionated by electrophoresis in $12 \%$ polyacrylamide gel- $0.1 \%$ SDS and electroblotted onto nitrocellulose filters. The IGFBPs were detected by incubation with a mixture of ${ }^{125}$ I-labelled IGF-I and IGF-II $(1 / 1 ; 500,000 \mathrm{cpm}$ per filter), and after washing the filters were exposed with an X-ray sensitive film.

\section{Results}

In order to verify the presence and determine eventual variations in the content of IGFBPs during gestation of sheep, samples of amniotic fluid were collected on different days of pregnancy. They were then subjected to analysis by PAGE under reducing conditions, followed by ligand blotting (Fig. 1). A major IGFBP migrating at approximately 40 to $45 \mathrm{kDa}$ was detectable from the earliest point analyzed (41st day of gestation) and increased dramatically from day 90 to reach a maximum by day 106 . Smaller IGF-binding molecules with a molecular mass of approximately $35 \mathrm{kDa}$ and $25 \mathrm{kDa}$ appeared at 90 days with a maximum at day 106 of pregnancy. These smaller IGFBPs were not present until the 70th day of gestation.

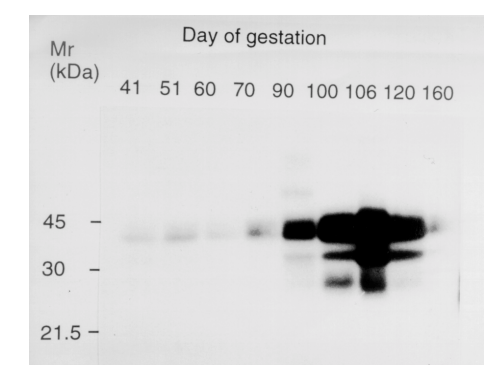

Fig. 1. IGFBPs in sheep amniotic fluid during gestation. Thirty $\mu$ l of sheep amniotic fluid was fractionated by SDS-PAGE, transferred to a nylon membrane and revealed by ligand blotting. For detection of binding proteins a mixture of radioiodine-labelled IGF-I and IGF-II was used. Other conditions are described in the Material and methods section 
For the study of mitogenic activity, samples of amniotic fluid were co 1lected at the 10th week of gestation, i.e. the time of maximum growth of fetal membrane. At that time, the amniotic fluid contained a single 40-45 kDa IGFBP species as revealed by ligand blotting (Fig. 1).

The electrophoretic profile of whole sheep amniotic fluid obtained by $\mathrm{n}$ ative PAGE has shown that this material contains a number of different proteins (data not shown). Separation of the proteins of amniotic fluid exhibiting mit ogenic activity by gel chromatography on a Sephadex G-50 column together with determination of the mitogenic activity of individual fractions are shown in Fig. 2. The major portion of material determined by measurement of absorbance at $280 \mathrm{~nm}$ (full line) was eluted in the total volume of column and probably re presents oligopeptides (fractions No. 35-50) of intermediate size without mit ogenic effects. When testing each chromatographic fraction for mitogenic activity (solid circles), it appeared that the biological activity was separated into two peaks. One of these peaks (I) eluted immediately after the void volume of the column, while the other (II) coincided with the position of elution of ${ }^{125}$ I-IGF-I. This pattern was highly reproducible.

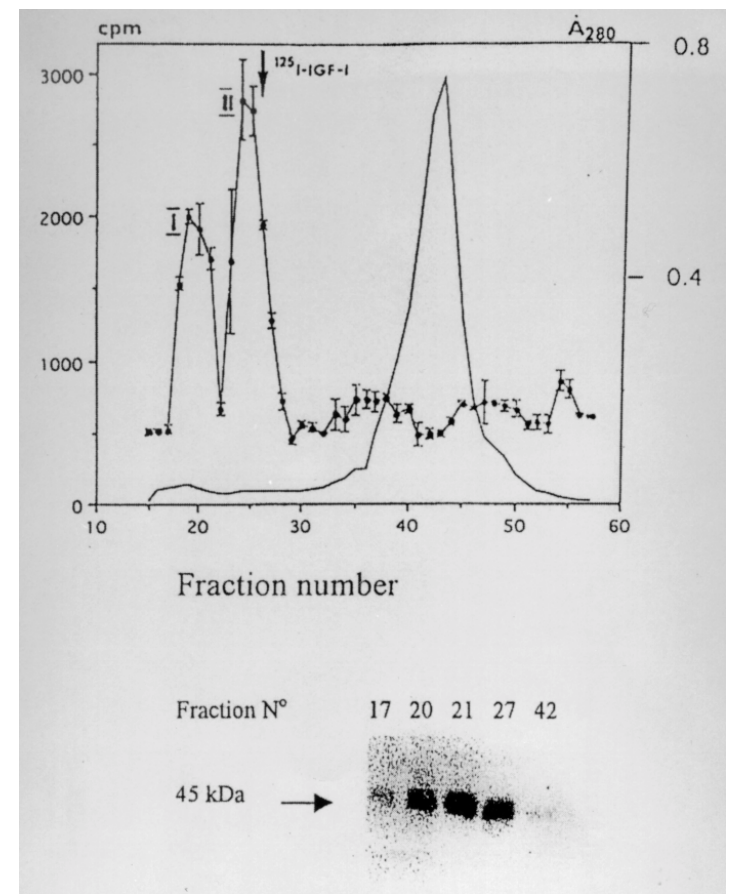

Fig. 2. Mitogenic activity of sheep amniotic fluid after separation by Sephadex G-50 chromatography. Column $(3 \times 90 \mathrm{~cm})$ was loaded with $400 \mathrm{mg}$ of lyophilized amniotic fluid in $10 \mathrm{ml}$ of $10 \%$ acetic acid and eluted with the same solution of acetic acid at a flow rate of $9.5 \mathrm{ml} \mathrm{per} \mathrm{h}$. Fractions were measured at $280 \mathrm{~nm}$ (A, full line) and were tested for mitogenic activity (cpm, solid circles). Arrow shows elution position of ${ }^{125}$ I-IGF-I. The ligand-blot of some fractions is shown below 
The electrophoretic analysis of the fractions with mitogenic activity (17 up to 42) followed by ligand blotting showed that significant amounts of IGFBPs with $\mathrm{M}_{\mathrm{r}}$ of $40-45 \mathrm{kDa}$ were present in the first peak (bottom part of Fig. 2). However, the elution pattern of the IGFBPs was not a sharp peak and in some experiments extended also into the second peak. The immunoblotting of these fractions using antibodies against human IGFBP-1 and IGFBP-3 was unsuccessful.

\section{Discussion}

It has been known for at least two decades that human amniotic fluid co ntains, besides IGF-I and IGF-II, also specific proteins that bind both som atomedins with high affinity (Drop et al., 1979). The formation of firm complexes changes the transport of IGFs to cell receptors, prolongs the biological half-life of IGFs, and thus profoundly influences the mitogenic activity of IGFs (McCusker and Clemmons, 1992).

In this paper we describe the presence of binding proteins in sheep amniotic fluid in relation to gestation time. At the 10th week of pregnancy IGFBPs of an approximate molecular mass of 40-45 $\mathrm{kDa}$ were found in sheep amniotic fluid, while later on other smaller IGFBPs appeared $\left(\mathrm{M}_{\mathrm{r}}=35\right.$ and $\left.25 \mathrm{kDa}\right)$. The peak concentration of all types of IGFBP appeared at the end of the third trimester. A similar but not identical pattern has been reported for IGFBP in human amniotic fluid, where the appearance of maximum concentration was shifted to the end of the second trimester of pregnancy (Povoa et al., 1984). Our results also show that immediately before parturition the level of all types of IGFBPs decreased dramat ically. On the basis of these findings it appears that in late gestation the modulatory role of IGFBPs in the inhibition of mitogenic effect of IGFs is less expressed in sheep than that observed in humans (Koistinen et al., 1993).

We have recently reported that sheep amniotic fluid displays mitogenic activity in the culture of mouse fibroblast cells used in our assay only after $\mathrm{r}$ emoving the small molecular fraction (Blahovec et al., 1997). Chromatography of the protein fraction of amniotic fluid on Sephadex G-50 column has led to sep aration of the mitogenic activity into two peaks. We suppose that, similarly as in human amniotic fluid, the whole amounts of somatomedins are bound to IGFBPs also in sheep. That is why we used acidic gel chromatography where $10 \%$ acetic acid caused the dissociation of IGF-IGFBPs into both its components (Merimee et al., 1984). Under these conditions, in the region of low optical density we $u$ nexpectedly found two peaks with stimulating effects on the incorporation of ${ }^{3} \mathrm{H}$ thymidine into the DNA of mouse fibroblasts. The second peak corresponds to somatomedins because it co-eluted with ${ }^{125}$ I-IGF-I, which was loaded on the column and chromatographed under the same experimental conditions. These e xperiments were repeated several times with the same results. 
The position of the first peak corresponds to the proteins with a higher $\mathrm{m} o-$ lecular mass of approximately 40-45 $\mathrm{kDa}$. PAGE performed under reducing co nditions and subsequent ligand blotting showed that the first peak contained binding proteins. In conclusion, we have shown that sheep amniotic fluid contains, in add ition to IGFs, other mitogenically active component(s) characterised by an apparent molecular weight higher than that of IGF-I or IGF-II. Ligand blotting has revealed that this (these) component(s) is (are) probably binding protein(s), but the presence other unknown growth factors cannot be e xcluded.

\section{Acknowledgements}

This study was supported by grants from INSERM (Paris), Tempus (PHARE) from the EU, and the VEGA and VE 06 grants from the Slovak government.

\section{References}

Blahovec, J., Kostecká, Z., Mešter, J. and Cavaille, F. (1997): Peptidic components of sheep amniotic fluid regulate cell proliferation of BP-A31 cells. Vet. Med. Czech 42, 185-189.

Drop, S. L. S., Valiquette, G., Guida, H. J., Corvol, M. T. and Posner, B. I. (1979): Partial purification and characterization of a binding protein for insulin-like activity (ILAs) in human amniotic fluid: a possible inhibitor of insulin-like activity. Acta Endocrinol. (Copenh.) 90, 505-510.

Elgin, R. G., Busby Jr., W. H. and Clemmons, D. R. (1987): An insulin-like growth factor (IGF) binding protein enhances the biologic response to IGF-I. Proc. Natl. Acad. Sci. USA 84, 3254-3258.

Hossenloop, P., Seurin, D., Segovia-Quinson, B., Harduin, S. and Binoux, M. (1986): Analysis of serum insulin-like growth factor binding proteins using Western blotting: use of a method for titration of binding proteins and competitive binding sites. Anal. Biochem. 154, 138-143.

Itakura, A., Kurauchi, O., Moreikawa, S., Furugori, K., Mizutani, S. and Tomoda, Y. (1997): Human amniotic fluid mitogenic activity for fetal alveolar type II cells by way of hepatocyte growth factor. Obstet. Gynecol. 89, 729-733.

Kelly, E. J., Newell, S. J., Brownlee, K. G., Farmery, S. M., Cullinane, C., Reid, W. A., Jackson, P., Gray, S. F., Primrose, J. N. and Lagopoulos, M. (1997): Role of epidermal growth factor and transforming growth factor alpha in the developing stomach. Archives of Disease in Childhood. Fetal and Neonatal Edition 76, F158-F162.

Koistinen, R., Itkonen, O., Selenius, P. and Seppälä, M. (1990): Insulin-like growth factor-binding protein-1 inhibits binding of IGF-I on fetal skin fibroblasts but stimulates their DNA synthesis. Biochem. Biophys. Res. Commun. 173, 408-415.

Koistinen, R., Angervo, M., Leinonen, P., Hakala, T. and Seppälä, M. (1993): Phosphorylation of insulin-like growth factor-binding protein-1 increases in human amniotic fluid and decidua from early to late pregnancy. Clin. Chim. Acta 215, 189-199.

McCusker, R. H. and Clemmons, D. R. (1992): The insulin-like growth factor binding proteins: Structure and biological functions. In: Schofield, P. N. (ed.) The Insulin-like Growth Factors. Structure and Biological Functions. Oxford University Press, Oxford, New York, Tokyo, 1992, pp. 110-149.

Merimee, T. J., Grant, M. and Tyson, J. E. (1984): Insulin-like growth factors in amniotic fluid. J. Clin. Endocrinol. Metab. 59, 752-755.

Povoa, G., Enberg, G., Jornvall, H. and Hall, K. (1984): Isolation and characterization of a somatomedinbinding protein from mid-term human amniotic fluid. Eur. J. Biochem. 144, 199-204. 